\title{
Muiris O'Sullivan's “New Storytelling”: The Art of Twenty Years A-Growing
}

\author{
Thomas F. Shea
}

University of Connecticut, USA

Copyright (c) 2018 by Thomas F. Shea. This text may be archived and redistributed both in electronic form and in hard copy, provided that the author and journal are properly cited and no fee is charged for access.

\begin{abstract}
Since its publication in 1933, Muiris O'Sullivan's Fiche Blian ag Fás (Twenty Years A-Growing) has been limited and distorted by critics who view the memoir through a lens shaped by prior assessments of Tomás Ó Criomhthain's earlier Blasket autobiography, An tOileánach (The Islandman). Muiris Mac Conghail voices the standard perspective when he states, "It was the publication of Tomás Ó Criomhthain's An tOileánach, in 1929, which both acted as an incentive and provided an exemplar to Muiris" (150). O'Crohan's autobiography certainly inspired O'Sullivan; however, Muiris's more literary sensibility set him on his own inscriptive journey during which he creates a new type of narrative, one which creatively interweaves oral traditions with the contours of the novel. As we investigate what Pádraig Ó Fiannachta terms the author's nua scéalaíocht, or "new storytelling" techniques, we can more fully appreciate O'Sullivan's subtle dexterities as both traditional storyteller and novelistic craftsman.
\end{abstract}

Key Words. Muiris O’Sullivan, Blasket Islands, Béaloideas, Novel, Tragedy.

Resumen. Desde su publicación en 1933, el libro de memorias Fiche Blian ag Fás (Twenty Years A-Growing), de Muiris O'Sullivan, ha sido considerado como obra menor al ser analizado por los críticos bajo el prisma de una anterior autobiografía relacionada con las islas Blasket, An tOileánach (The Islandman), de Tomás Ó Criomhthain. Muiris Mac Conghail por ejemplo mantiene la opinión tradicional sobre esta obra cuando opina lo siguiente: "Fue la publicación del libro de Tomás Ó Criomhthain An tOileánach en 1929 lo que sirvió de estímulo y a la vez de modelo para el libro de Muiris" (150). Ciertamente la autobiografía de O'Crohan (nombre en ingles de Ó Criomhthain) inspiró a O'Sullivan; sin embargo hay que señalar que Muiris tenía una sensibilidad más literaria, lo cual le sitúa en un itinerario narrativo propio, en un nuevo modelo donde se entrecruzan de forma creativa la tradición oral y el perfil de la novela. Si analizamos aquí lo que Pádraig Ó Fiannachta define como nua scéalaíocht o nueva forma de contar historias, se podrá apreciar en su totalidad la sutil destreza con la que O'Sullivan muestra sus dotes tanto de contador de historias tradicional como de experto novelista. 
Palabras clave. Muiris O’Sullivan, islas Blasket, folclore tradicional, novela, tragedia.

Since its publication in 1933, Muiris O'Sullivan's classic, Fiche Blian ag Fás, translated as Twenty Years A-Growing, has enjoyed enthusiastic acclaim across the globe. Muiris Mac Conghail confirms that the Irish edition "was an instant success for the author" and, when the translation was published soon after, "it achieved extraordinary success in the Englishspeaking world" (151). While praise has been plentiful, the book is often extolled using, to my mind, limited and misguided criteria. Critics usually take a tack similar to Percy Hutchinson's when he lauds "Maurice O'Sullivan's simple, lilting pages ... All is told with an artlessness which captures in recollection the narrow, yet intense, joys of childhood ..." (1). In "The Last of His Tribe," B.J. Coman states: "The account has a particular directness, a delightful naivety, and an enormous sense of authenticity" (71). When critics use terms such as "artlessness", "directness", and "authenticity", they seem to be evaluating O'Sullivan through a lens shaped by prior assessments of Tomás Ó Criomhthain's An tOileánach (The Islandman). Mac Conghail states, "It was the publication of Tomás Ó Criomhthain's An tOileánach, in 1929, which both acted as an incentive and provided an exemplar to Muiris" (150). Ó Criomhthain's autobiography certainly inspired O'Sullivan; however, Muiris's more literary sensibility set him on his own inscriptive journey during which he creates a new type of narrative, a hybrid which creatively interweaves oral traditions with components of the novel. Pádraig Ó Fiannachta, one of the most discerning readers of Blasket literature, tells us:

Muiris, you know, brings the art of storytelling from the Béaloideas [traditional folklore] right into the events of everyday life. So I invented the title nua scéalaíocht [new storytelling] to his style like, that this is nua scéalaiocht. You had the seanscéalaiocht which was reciting an old story, an old tale. But Muiris actually made it all the important events [of his life] - made them a sort of story in their own ... (Ó Fiannachta)

The particular qualities of this nua scéalaíocht, or new storytelling, have remained largely overlooked but, when examined in detail, they prove both striking and provocative. With a skilled hand for design, O'Sullivan added two crucial chapters during the editing process and arranged those chapters strategically. Utilizing classic peripeteia, he ultimately segues into an aura of tragic lament that radically contrasts with the exuberant, wide-eyed wonder dominating the first four-fifths of the memoir. O'Sullivan also infuses features from fiction, especially the novel, with traditions of autobiography. When we appreciate more fully the hybrid qualities of the text, we also find ourselves reassessing the critical heritage shading and, so far, warping previous readings of Twenty Years A-Growing.

As a narrative craftsman grounded in the arts of oral performance, O'Sullivan is keenly aware of audiences and maneuvers them well throughout his memoir. He often creates multi-tiered layerings in which strata of Island "performers" are commented on by neighbor "audiences" who then, themselves, become actors for successive viewers. One notable example occurs in Chapter Seven, titled "A Shoal of Mackerel". As the Islanders sight swarms of gannets following a large school of fish closing in toward shore, all the able-bodied men gather their nets and rush to their curraghs for an evening of intensely active fishing. The women of the Blasket recognize a high time when they see one emerging, and they all gather on the hill at the top of the White Strand to watch and vocally encourage their men. As boys, Muiris and his best friend, Tomás Owen Vaun, know enough to select a position on the periphery, the better to take it all in: 
There was no understanding the old women now who were foaming at the mouth with their roaring.

'Your soul to the devil', cried one to her husband, 'throw the head of your net behind them!'

'Musha, you're my love forever, Dermod!' cried another when she saw her husband making a fine haul of fish.

One woman, Kate O'Shea, her hair streaming in the wind like a madwoman's, was screaming: 'The devil take you, Tigue, draw in your nets and go west or to the south of the Sound where you will get fish for the souls of the dead. Och, my pity to be married to you, you good-for-nothing!'

'May the yellow devil fly away with you, you have the place destroyed with your noise!' shouted one of the fishermen when he heard the screams ashore.

As for Tomás and me, our hearts were black with laughing at the old women. Their shawls thrown off, waving their arms at their husbands, they called to them to come here and to come there around the fish, until the fish themselves seemed to be distracted by them. (O’Sullivan 75-76)

George Thomson provides a contextual appraisal that helps us more fully appreciate such a passage: "In all respects, save for the use of the first person, these autobiographical tales were indistinguishable from the traditional tales. All alike were products of a single art of storytelling which had been cultivated continuously since prehistoric times" ("Muiris").

The theatrics of the scene then shift as the wives calling to and commenting on their fishing husbands take center stage, drawing their own audience of the older men of the village who are past their prime, no longer active fishermen. Old Mickil, Shaun Fada, Shaun Michael, and the Púncán observe the women observing their husbands, and the old men get involved themselves:

'Achván, achván, aren’t they the mad crowd?' says Shaun Michael.

'They are, musha, so', agrees the Púncán, throwing out a big spittle of tobacco.

'By the devil's body, is it going out of your wits you are?' cries Shaun Fada to the women.

'Arra, your soul to the devil, my lad, what ails you?' says old Mickil, stretched out on the grass.

'What ails me is a pain in my head listening to those seal-cows of women' ...

The women were growing hoarse now, especially Kate O'Shea.

'Kate is giving out', says Shaun Michael.

'The devil a wonder, short of her having a throat of iron', says Seán Fada.

'Faith', says old Mickil, rising up on his elbow, 'I am here for half an hour now and you wouldn't find a bull-seal to bellow the like of her ever since'. (O'Sullivan 76-77)

Such a scene features "Island Cross-Talk" among the three groups: the fishermen pulling in their nets full of mackerel, the cheerleading audience of wives yelling to/at their husbands, and an assembly of old men, reclining at their ease in the background, adding a third layer of "sage" commentary. Tim Enright explains the term "Island Cross-Talk" in this manner: "The shafts fly at known targets and the retorts are expected. It is verbal fencing, in the cut and thrust of which the young join freely with the old ... Needless to say, [the verbal thrusts and parries] would be recounted and savored by the Islanders ... Humour was constantly bubbling on their lips" (“Introduction” 3). 
To complete the comic drama, O'Sullivan segues into Act Three in which Muiris's father, Seán Lís (Shaun Leesh), finds his nets so full that he can't possibly fit all the fish in his curragh:

'Look', says Tomás to me, 'your father is drawing in his net again' . . .

At that my heart rose with delight. My father drew in the end of the net. There was a mackerel in every mesh.

'Upon my soul, I doubt he won't land all he has', said Shaun Fada.

'No matter for him', said the Púncán, throwing another spittle of tobacco, and a big yellow streak down his chin from chewing it.

'The devil, my lad, he will have to cut the net', said old Mickil.

'What's that you are saying?' said the Púncán.

'What I am after saying, devil'.

'Och, whist so, whist so'.

'Arra, devil take you, man, what do you know about fish?'

'I killed as many as you ever did,' retorted the Púncán spitting again.

'Musha, it is the few you ever killed, old crow!'

My father's curragh was now hardly an inch out of the water. He drew out his knife $\ldots$

It was then there was a commotion among the curraghs when they saw my father cutting his net. They began rushing up to get the cut piece ...

When Kate O'Shea saw the confusion out to sea, she let out a great shout. 'Musha, your soul to the devil, Shaun, keep it for Tigue!' she cried to my father.

Knowing that Tigue had not much in the world, my father shouted back to her to go and call him. She leaped and darted out onto a spur of rock, calling her husband who was back at the mouth of the Narrow Sound ...

When Tigue heard her he turned back. 'What ails you?' he cried.

'Hurry on, in the devil's name; Shaun Leesh has his nets cut and he is keeping the piece for you'.

Without another word Tigue rowed hard to the east and my father gave him the piece he had cut from the net. Tigue drew it in and soon his curragh was as low in the water as my father's. (O'Sullivan 77-78)

Here, O'Sullivan's skills with orchestration can be heard through the interplay of several vocal ranges. Having first directed their cross-talk at the women of the village, the old men shift their focus and redirect their barbs at one another. Old Mickil, who first argued with Sean Fada, now turns on the Púncán, and they spar about each other's dubious fishing prowess way back when. The elderly commentators wind up performing for each other just as the wives are performing within their own group as well as for their fishing husbands. Our narrator, Muiris O'Sullivan, is obviously performing too as he smuggles in phrases and details that would certainly enhance an oral rendition. Most times when the Púncán gets to speak, his tobacco spitting and "big yellow streak" of juice dribbling down his chin receive even more of our attention than the actual words uttered. As George Thomson reminds us, the histrionics of such a rendition are crucial to our appreciation of the drama:

There are two sides to the art of storytelling: the story itself, and the extraneous means by which the narrator enhances its effects - the inflections of the voice, the manual gestures, the laughter and the tears. The narrator is always something of an actor, who depends for his inspirations on the audience. He is quick to react to their 
response, and as they are carried away, so he too is moved to surpass himself, until all alike are spellbound. (Island 55)

With pen in hand, O'Sullivan is "always something of an actor", one who learned his craft listening to his grandfather's renditions and then delivering performances himself as he entertained neighbors gathered before an Island hearth. As Lauri Honko points out, both oral and written traditions are best appreciated "from the point of view of the story-telling situation [and] the narrative technique" (8). We should also note the degree to which O'Sullivan asks for, and receives, our willing suspension of disbelief. Muiris often interweaves his memoir with details that simply have to be fictive. When he described the chorus of wives calling directions to the fishermen, he adds the zestful coup that all the yelling affects the cerebral concentration of the underwater quarry: "[the wives] called to [their husbands] to come here and to come there around the fish until the fish themselves seemed to be distracted ..." (O'Sullivan 75-76). O'Sullivan also adds gratuitous details as if he can omnisciently read his father's mind: "Knowing that Tigue had not much in the world, my father shouted back to her [Kate O'Shea] to go and call him" (O'Sullivan 78). When we think about it, the entire episode must be taken as a delightful autobiographical romp with improbable, inventive details serving as embellishments. The women on the cliff above the strand are calling to their husbands who are often more than a quarter mile from shore. Even if Kate O'Shea can bellow like a bull seal, and even if her tirades were aided by an outgoing wind, that same wind would prevent her husband's replies - or those any other fisherman from being audibly discernable onshore. To appreciate O'Sullivan's writing as highly crafted, we would do well to listen to Declan Kiberd who says:

I think some of the passages of the book are not credible if you read them as autobiography ... He's so good at describing conversations which involve multiple numbers of people - again that's a technique you get in the novel but not so easy in oral narration where you are kind of stuck with the narrator ... It's very hard to have five or six or seven people all talking in the same scene in an oral narration but you can do that in the novel and that's, of course, part of the charm of Fiche Blian ag Fás. ("Muiris")

Many other chapters of the memoir also feature such fictive conversations and build themselves through similar layering techniques, embedding story within story within story. ${ }^{1}$

We can also discern the novelistic qualities of Twenty Years A-Growing when we uncover the ways O'Sullivan strategically arranges his chapters. During the editorial process, not only was the much longer original manuscript pared quite a bit; two highly significant chapters were also added which consequentially shift the form and impact of the organic whole. The first of the added chapters, titled "An American Wake," centers on the departure of Muiris's oldest sister, Maura, who intends to emigrate to the U.S. with Peg Sayers' daughter, Kate Peg. Maura is the first of Muiris's siblings to wrestle with emigration, and the chapter inaugurates a strong current of ambivalence new to the memoir. The rendition of Maura's impending departure centers on her simultaneous strong attraction to - and vigorous repulsion from - the entire prospect of departing her Island home:

Kate Peg was constantly coming to the house now and she and Maura talking of nothing but America. They would run across to the wall where pictures from Springfield [Massachusetts] were hanging. 'Oh', Kate would say, 'we will go into that building the first day, Maura'. Then the two of them would run out on the floor dancing for joy. (O’Sullivan 197) 
But these scenes of euphoric anticipation are often offset by their opposite, with confusion and sorrow overtaking Maura as well as the rest of the family:

Maura was crying everyday now. 'Musha, I don't know in the world', she would say when she washed the plates, 'will the day ever come when I will be washing these again'.

It was the same when she would be sweeping the floor. She would look at the broom and the tears would fall. Then she would run across to my dog Rose and catch her up in her arms. 'Musha, Roseen, isn't it many a day the two of us were west on the White Strand, I throwing stones into the water and you swimming out after them!' ... I noticed his cap far down over my father's eyes that evening as I had never seen it before. Eileen was in the far corner crying to herself. (O'Sullivan 198, 197)

O'Sullivan's placement of "An American Wake", inserted to follow the chapter titled "The Wedding Day", proves pivotal. In "The Wedding Day", when he was a mere sixteen, Muiris and his girlfriend Mauraid had crossed the Blasket Sound to attend a marriage on the mainland. Looking back at his Island home, Muiris shocked Mauraid with a startling prediction:

'Faith, Mauraid ... the times are gone when a man and a woman could marry there ... Don't you see it yourself? The most important livelihood - that's the fishing - is gone under foot, and when the fishing is gone under foot the Blasket is gone under foot, for all the boys and girls who have any vigour in them will go over the sea; and take the tip off my ear, Mauraid, if that day is far hence'. (O'Sullivan 187)

This prescient pronouncement is reinforced and fulfilled with the addition of the "An American Wake" chapter. Not only do we see Muiris's sister Maura emigrating; she also diligently saves her wages in America to send passage money back to the Blasket for her siblings. Less than two years later, brother Seán is able to join her in America and then, a year after that, sister Eileen is sent her travel fees. The plan was for the O'Sullivan children to continue this sequence and for the youngest, Muiris, to also be sent ship's fare so that he could eventually follow his siblings to the States. ${ }^{2}$

The dynamics of powerful ambivalence established in "An American Wake" also segue significantly into the chapter that follows. Titled "The Stranger," this chapter centers on Muiris's first meeting with the English scholar George Thomson who visited the Blasket in the summer of 1923. While "An American Wake" introduces the theme of ambivalence about leaving the Island, "The Stranger" augments those currents and redirects their flow, so that O'Sullivan becomes tormented about emigration, especially during George's visits each subsequent summer. Eventually, Thomson wound up shaping O'Sullivan's life irrevocably; he served as the crucial catalyst for Muiris's leaving the Great Blasket - but not via emigration to America. Instead, coerced by George during a series of summer visits, Muiris finally decided, in 1927, to travel to Dublin and enlist in the newly established Free State police force, the Garda Síochána. That crucial, life-changing development ultimately fostered the writing, editing, and publication of Fiche Blian ag Fas as well as its translation, Twenty Years A-Growing. After completing his Civic Guard training in Dublin, O'Sullivan was stationed out west, in Connemara, Galway. During the early 1930s, George Thomson was fortuitously close by, having recently received a faculty appointment to teach the Greek classics through the Irish language at University College Galway. After witnessing the enthusiastic reception of Tomás Ó Criomhthain's autobiography, An tOileánach, Thomson 
encouraged Muiris to try his hand at his own life story. Mark Quigley stresses that Ó Criomhthain had to be repeatedly cajoled by Brian Ó Ceallaigh into writing his autobiography: "Ó Criomhthain embarks upon the project under significant duress [and] writes An tOileánach as a job ... simply the fulfillment of a task" $(399,402,403)$. Not so with O'Sullivan: he enthusiastically plunged into the writing of his memoir and worked closely with Thomson in Galway, consulting regularly with his friend and advisor when editing Fiche Blian ag Fás. ${ }^{3}$

The second chapter added during the editing process is the final one, titled "Conclusion", which also enhances our appreciation of O'Sullivan's feel for narrative architecture. The potent ambivalences introduced during "An American Wake" intensify during this final chapter as Muiris records his return to the Blasket for the first time since departing to join the Gardaí in 1927. After being stationed in Connemara, serving first at Inverin and then at Carraroe, Muiris returned to the Great Blasket in 1929. Early in the chapter, he dwells on the joys of homecoming. Rounding Slea Head, at the end of the Dingle peninsula, he gazes out at the Blasket Islands for the first time in two years: “ ... how my heart opened when I reached Slea Head and saw the Blasket, Inish-na-Bró and Inish-vickilaun stretched out before me in the sea to the west! I was as gay as a starling ... " (O'Sullivan 271). When he arrived at the little harbor of the Blasket, all the women of the village were waiting to greet him and gushed as he climbed the hill toward his home:

When we came to the quay in the Blasket, I thought I would never reach the house. 'Oh, King of Angels', cried one old woman, 'isn't it a fine man you have become!' 'Musha, how is every bit of you?' cried another.

'Musha, isn't it you have the great shell of flesh!' cried a third ...

As I approached the house, I saw my grandfather standing in the doorway. When he saw me, he remained there standing, shedding tears of joy.

'Musha, how are you since, daddo?'

He could not speak yet, but embraced me. (O’Sullivan 272)

The euphoria of his return, however, is simultaneously complicated by an enervating pall of absence. At the same time that Muiris is overjoyed with the exuberant welcomes he receives, he cannot escape the recurring "news" of what has been transpiring during the intervening two years: "this boy was gone and that boy, this girl and that girl gathered away to America" (O'Sullivan 271). This focus on the departure of the Blasket's youth has been building as a leitmotif for quite some time in the last third of the memoir. As early as the chapter "The Wedding Day", previously referred to, Muiris had a moment of insight while musing on the rising moon:

The night was falling. I walked up from the cliff's edge a little way and sat down, As I looked out again to Mount Eagle I saw a sickle of gold climbing up behind the hill ... I seem to see before me, full of bright laughter, all the boys and girls who were with me when I was a child. I see them running down the lanes and hiding themselves - the game we used to play in the moonlight - and I hear old Paddy crying in the distance 'Caught' ... (O'Sullivan 184)

This passage subtly maneuvers time-frames, creatively producing a series of superimposed images. During the act of remembering, Muiris would have been sixteen, recalling a game akin to Hide-and-Seek taking place when he was much younger - perhaps age eight or nine. But he frames this memory in the present tense through verbs such as "I see them running" and "I hear old Paddy". The shift in verb tense effectively overlays the act of recollection as a 
teen with the events as they happened as a child. The scriptive double exposure is made more provocative when we consider that O'Sullivan is writing about his teenage recollection of childhood gaming more than ten years after that memory occurred. The present moment of writing, while he is stationed in Connemara during the early 1930s, is superimposed over the previous two time-frames, one as a sixteen-year-old, and one as a child, creating a palimpsest through which we glimpse the Blasket's eventual abandonment. ${ }^{4}$

In addition to amplifying the notes of ambivalence, O'Sullivan also displays admirable skill sprinkling in adumbrations as he crafts his memoir. I am using "adumbration" in the sense that, very early in his autobiography, Muiris subtly sounds or "prefigures indistinctly" tonal themes that we hear more fully developed in the latter stages of the composition (American Heritage Dictionary). For example, on 15 March 1927, Muiris departed the Great Blasket to commence his life-altering journey and join the ranks of the Garda Síochána. After a row of three miles across the Blasket Sound, Muiris first walks five miles to Ballyferriter to obtain a copy of his baptismal certificate from the parish priest. Then, he must find his way to Dingle Town, an arduous walk of another ten miles, where train service will eventually bring him to Dublin. Between Ballyferriter and Dingle, among many dirt lanes, winding roads, and confusing crossroads, he repeatedly feels lost and needs to ask directions, but the journey culminates with a homecoming of sorts. Easily forgotten by many readers, O'Sullivan's memoir begins in Dingle Town, where he spent the first seven years of his life. Born into a growing family on the Blasket, Muiris was subsequently placed in a Dingle orphanage/institution when he was six months old because his mother died and his father did not feel capable of caring for a fifth child. In 1911, when Muiris's father reclaimed his sevenyear-old son, one of their last stops in Dingle was the shop of Martin Kane where they could enjoy a meal prior to heading for Dunquin and the row in to the Island:

We went into the shop of Martin Kane in the big street.

'God bless your lives', said Martin ... 'Who is the lad along with you?'

'It is a son of mine', said my father.

'I would never have known him. Do you like to be going to the Blasket?' said he to me.

'I do, indeed'.

'Upon my word', said Martin, 'the day will come when you will turn your back on the place, my boy'.

'It will never come', said I. (O'Sullivan 18)

Now, at age twenty-three, on his way to join the Garda, Muiris's return to Dingle town underscores multiple ironies. He immediately heads for that same shop of Martin Kane where he will seek food and a bed before catching the train to Dublin in the morning. Marin Kane does not recognize Muiris after all these years, and O'Sullivan obviously relishes constructing the following scene:

I strolled into the kitchen and my heart full of delight to have accomplished the journey of the day. Martin rose from the chair.

'Where did you come from?' said he, 'or who are you at all?' ...

'Faith', said I, 'I am no Irishman anyway'.

'You are not?' said Martin in astonishment.

'I am not indeed, though I have Irish blood in me'.

Both he and his wife were now looking at me intently.

'When did you come to Ireland, so?'

'Today'. 
'And how the devil then did you pick up the fine Irish?'

'Arra, my dear sir, and isn't it we who have the best Irish?'

'It seems so', said he, looking at me between the eyes, 'but if you are not an Irishman what are you?'

'I am a Blasket man, my boy', said I. (O’Sullivan 224)

This exchange dynamically interacts with Muiris's first meeting with Martin Kane. As narrative designer, O'Sullivan coordinates these scenes to counterpoint the radical disparities of his journeys. At age seven, leaving the orphanage, he was going home to the Blasket for the first time in his memory; now at age twenty-three, he is leaving home for a new life far from the Island. Martin Kane's prediction all those years ago has obviously proven prescient. As a seasoned storyteller who knows his timing, Muiris saves the highly ironic twist for last. He concludes his conversation with Martin by establishing his distinct identity: "I am a Blasket man"; however, today's journey, on his way to Dublin, has begun the irrevocable process of forsaking that identity as well as his Island home.

The contexts we have just been considering should prompt a thoughtful re-appraisal of Twenty Years A-Growing and its critical heritage. Ever since its publication in 1933, the memoir has been celebrated for its youthful, wide-eyed cheerfulness. The usual perspective is to see Twenty Years A-Growing as an upbeat, optimistic book, exuding the buoyancy of spirited boyhood. Cathal Póirtéir asserts, "His book is by far the happiest book written by any of the 'Blasket Trinity'. It is mostly a book about a young boy growing up happily in his island community ... it describes a wonderful, optimistic carefree youth ... " (23). Sean Ó Lúing states, "What O'Sullivan described was not so much the physical island as the aura of youth and wonder that is distilled into those magic, fleeting years that are lived before twenty" (149). Alan Titley, one of the foremost experts on Blasket Island literature, adds: "Fiche Blian ag Fás is a book that is full of light, you feel the sun is shining ... and everyone likes one another, and there's dancing, and there's music, and there's singing, and there's joy - you get the sense of people, you know, skipping around ..." (Titley). While such assessments are predominantly accurate, I would like to reassess O'Sullivan's reputation by exploring more fully the aura of tragedy that emerges in the final fifth of this novelistic memoir. Because the word "tragedy" has spawned a multitude of definitions since Aristotle's Poetics, we should qualify the term carefully. The O.E.D. offers a most apt definition: "a doleful or dreadful tale; a passionate complaint" (Compact 3373). I am arguing that Twenty Years A-Growing shifts to a tone of passionate grief and even dread in its final chapters when Muiris realizes that he must trade the idyllic life he has enjoyed growing up on the Blasket for a career on the mainland as a Garda.

When he finally completed his Gardai training, Muiris was assigned to a precinct in Connemara, an appointment which should have pleased him. The newly constituted Irish Free State desperately needed fluent Irish speakers for their barracks in the western seaboard Gaeltacht, so this would seem to play right into Muiris's hand. While he is thrilled to be finally finished with the Gardaî's tedious classes, books, and drilling, he soon discovers that his new uniform communicates a message that leaves him flummoxed. On the train from Dublin to Galway, O'Sullivan overhears two native Connemara peasants speaking Irish, which they assume the polis would never know. As they begin discussing the young Garda's presence in their compartment, Muiris cocks an ear, never letting on that Irish is his native language too. The first words he hears about himself are, "I dare say it is after the poteen the peeler is going" (O'Sullivan 266). Muiris is more than taken aback, wondering how a native Gaeltacht boy from the Great Blasket could be considered a "peeler." Derived from Sir Robert Peele, who instituted the first English police force in London, the term "peeler" eventually evolved to include the British-oriented Royal Irish Constabulary (R.I.C.), considered a 
colonial oppressor throughout Ireland. With the advent of the Irish Free State in 1923, the new Garda Síochána was supposed to embody an Irish-oriented, supportive police force, but the stigma of the R.I.C. - as a duly constituted arm of British imperialism - was not going to be erased any time soon. Pretending not to understand Irish, O'Sullivan discovers that he has precipitously acquired an identity that he never anticipated. The Connemara peasants continue:

'I dare say they [the peelers] were bad enough back in your place ... '

'Oh, musha, my son, the devil is in them all' ...

'Did you never hear that a peeler is not to be trusted until he's seven years under the clay? (O’Sullivan 267)

The suspicion and rejection conveyed through terms such as "them all" as well as the colloquial proverb "a peeler is not to be trusted until he's seven years under the clay" dramatically foreground how his fellow Irishmen will now look at Muiris's uniform and always see him as "other". Once off the train, walking to the barracks, trying to ingratiate himself with the locals he meets, Muiris is distraught to learn that even the little children will now treat him with trepidation:

I walked on again until I met a little boy, well clad in sheep's wool and carrying his bag of books. 'What is your name?' said I. He did not answer and tried to slip away. 'What is your name?' said I again.

He was looking into my eyes as if he was going to cry. At last he said tremulously: 'Colum O'Flaherty'.

'Have no fear, boy', said I, 'but tell me where is the barracks in this place?' (O’Sullivan 268-69)

When the lad tentatively points to a building up the road, he receives a sixpence piece from the scary newcomer, but Muiris will never forget that in donning the uniform of the Garda Síochána, "all's changed, changed utterly". Much to his dismay, he learns that his new official tunic designates him as an unwelcome step-child of Britain's R.I.C.

Assessing the shape of Twenty Years A-Growing, we should also re-consider how the final fifth of the narrative is discreetly configured through the agency of classic peripeteia, which the O.E.D. defines as "a turn right about, a sudden change esp. that on which the plot of a tragedy hinges" (Compact 2135). As we have seen, the notes of increasing sorrow were first sounded through a series of ambivalences, especially those surrounding the tensions of emigration. These notes were developed into resonant chords as O'Sullivan skillfully intersects those ambivalences with adumbrations of tragedy. During the first twenty chapters, Muiris frequently dwells on stunningly exuberant descriptions of the flora and fauna he finds so invigorating on the Great Blasket. One of many examples is showcased in Chapter 4 when Muiris and his childhood friend Tomás Owen Vaun spend an entire day at the back of the island, pursuing rabbits and hunting for puffins' eggs. Near the end of the day, the natural wonders surrounding him leave Muiris rapt:

The sun was now as round as a plate beyond the Teeracht to the west, and a path of glittering golden light stretched as far as the horizon over the sea ... Hundreds of birds were flying round, rabbits leaping from one clump of thrift to another, a sweet smell from the white heather and the fern, big vessels far out on the horizon you would think were on fire in the sunlight, a heat haze here and there in the ravines, 
and Kerry diamonds lying all around weakening my eyes with their sparkle. (O’Sullivan 38)

Passages like this - and there are many - exude a Wordsworthian thrill of participating in nature's sensuous wonders and animations. During the first four-fifths of the memoir, O'Sullivan repeatedly testifies to feeling a passionate reciprocity with nature's vibrancy. A peripatetic reversal, however, shocks us when O'Sullivan offers descriptions from the vantage of his new identity as a Civic Guard on the mainland. During the same scene quoted earlier, when Muiris is trying to find his way to the barracks in Connemara, his descriptions of nature sound drained and depleted:

I walked on till the road began to climb. I stopped and looked around.

King of Virtues, wasn't it a wretched poor place! There was not a hand's-breadth of lea-soil to be seen, but everywhere rocks and stones ... nothing but stones ... Then I noticed two calves pulling at a couple of hay-cocks hardly bigger than my head ... Musha, God help them, said I to myself, I don't know where is the field here to nourish them. (O’Sullivan 268)

Taking full advantage of hyperbole, with the amount of fertile soil tallied as smaller than "a hand's breadth", and the haycocks presented as only a tad bigger than a human head, O'Sullivan underscores the dismay that such a "wretched, poor place" fosters in a similarly wretched former Blasket man completely disheartened in his new life in the Gardaí.

One of the most sorrowful passages is given special emphasis in the added chapter "Conclusion" where it commands our attention as the penultimate paragraph of the entire narrative. After his first two years as a Garda in Connemara, Muiris returns to the Great Blasket and registers drastic alterations to his former Island home:

There was a great change in two years - green grass growing on paths for lack of walking; five or six houses shut up and the people gone out to the mainland; fields which had once had fine stone walls around them left to ruin; the big red patches on the Sandhills made by the feet of the boys and girls dancing - there was not a trace of them now. (O’Sullivan 272)

That last image proves most poignant and underscores O'Sullivan's dexterity with textual design. Those red patches atop the cliffs overlooking the Blasket's White Strand, patches where all vegetation had been worn away by dancing feet, had - for generation after generation - testified to youthful, energetic, communal vitality. In the earlier added chapter, "An American Wake," Muiris subtly prefigured his concluding chapter when he described the send-off celebration on the night before Maura emigrated:

On the last night young and old were gathered together ... and though music and songs, dancing and mirth were flying in the air, there was a mournful look on all ... No wonder, for they were like children of the one mother, the people of the Island ... the boys and girls every moonlight night dancing on the Sandhills or sitting together and listening to the sound of the waves from Shingle Strand ... (O'Sullivan 198)

Illuminated by moonlight, the Blasket children of Muiris's generation, like their parents and their parents' parents before them, wore away all grass growing atop the cliff, smoothing the earth with their dance steps as they celebrated a unique communal spirit "like children of the one mother". Constructing his memoir during the early 1930s, having himself departed the 
Great Blasket, Muiris knows - only too well - that those feet are now traversing the streets of Springfield, Massachusetts; Hartford, Connecticut; and, in Muiris's own case, the byways of Connemara.

In re-appraising the craftsmanship of Twenty Years A-Growing, we have to move beyond the standard assessment which typically agrees with J.V. Luce's statement: "There is ... in his writing a most attractive gusto and joie de vivre" (152). The notes of energetic enthusiasm and wide-eyed buoyancy certainly dominate the majority of the text. But recognizing the strategic placement of the two added chapters, we can clearly see O'Sullivan orchestrating a tonal reversal. As Lillis Ó Laoire notes, by "placing more emphasis on the joy and carefree nature of youth for most of its length," $O$ ' Sullivan makes "the spectre of emigration and change more effective when it finally appears" (1). Muiris's departure from the Great Blasket precipitates not only a surprising and unwelcome new identity as kin of the R.I.C., but nature itself, which he extolls with glorious descriptions on the Island, seems radically transformed from sensuous vibrancy to depressing desiccation. Ultimately, the memoir casts a disturbing and pervasive aura of plaintive elegy which attests to O'Sullivan's deft feel for shaping narrative plot. Speaking of the Blasket writers collectively, George Thomson provides a keen insight that should guide our re-assessment of Muiris O'Sullivan:

These authors were all versed to a greater or lesser degree in the art of storytelling. Their mode of speech and their outlook on life had been moulded by the traditional tales which they had inherited from past generations. What they did, therefore, was to select from their own experience a number of episodes which they had already cultivated as fireside tales and arrange them as a continuous narrative. In their hands, therefore, the transition from speech to writing was effected without a break. The magic of the fireside tale was carried over into print. (Island 32)

The oral qualities of O'Sullivan's prose cannot be denied, nor should we underestimate his skills selecting and arranging renditions to forge the anatomy of autobiography. Comparing O'Sullivan with Tomás Ó Criomhthain and Peig Sayers, Declan Kiberd avers, "Ó Súilleabháin, at home in print codes, ... is a far more modern and writerly sensibility" (Irish Classics 535). The artistries and craftsmanship of Twenty Years A-Growing deserve more critical attention; Muiris's "writerly sensibility" is best appreciated when we view his "new storytelling" as autobiography refracted through the prisms of both oral tradition and the novel.

\section{Notes}

1 This multi-tiered narrative layering also generates much of the comedy in Chapter 16 of Twenty Years AGrowing, titled "Matchmaking”. O'Sullivan's series of successive actors/audiences/actors displays affinities with many of Shakespeare's theatrical designs such as the box tree scene in Twelfth Night.

${ }^{2}$ While Maura, Seán, and Eileen all successively emigrated to America, Muiris's other brother, Micheál, left the Blasket to work as a tailor in Dingle Town.

3 O'Sullivan and Thomson edited the 500-page manuscript together during the early 1930s with George suggesting lots of deletions. At this time the chapters titled "An American Wake" and "Conclusion" were added. Thomson then typed out the revised draft in Irish "normalizing the spelling" (Luce 157).

${ }^{4}$ This type of narrative augury occurs several times during the memoir, fortifying the text with a frequently overlooked substructure. For example, since the opening of his memoir, Muiris repeatedly emphasizes how much he has always hated being under the thumb of any authority figure: "Very great indeed was the control that was over us" (O'Sullivan 1). Near the end, when he is finally accepted for the Gardaí, he laments, "Whatever happiness I had felt before it all left me ... I knew well I was under control again. It is often I had complained during my school-days and said to myself, if I were a grown man I would be content. But look at me now ..." (O’Sullivan 258). 


\section{Works Cited}

American Heritage Dictionary of the English Language. Fifth Edition. New York: Houghton Mifflin Harcourt, 2016.

Coman, B.J. "The Last of His Tribe: Maurice O'Sullivan and the Blasket Islanders". Quadrant 49, 3 (2005): 70-74.

The Compact Edition of the Oxford English Dictionary. New York: Oxford U.P., 1986 (1971).

Enright, Tim. "George Thomson: A Memoir". Island Home: The Blasket Heritage, by George Thomson. Dingle: Brandon, 1998. 117-50.

. 'Introduction". Island Cross-Talk, by Tomás O'Crohan. New York: Oxford U.P., 1986. 1-9.

Honko, Lauri. "Memorates and the Study of Folk Beliefs." Journal of the Folklore Institute 1, 1-2 (1964): 5-19. 6 October 2017. http://www.jstor.org/stable/3814027.

Hutchinson, Percy. "Youth and the Irish Islanders: Maurice O'Sullivan's Poetic and Entertaining Story of a Salty Community". New York Times. 6 August 1933. BR1. 22 September 2016. ProQuest Historical Newspapers. http://search.proquest.com/results/ F6BFFC26BBB54514PQ/1?accountid=14518.

Kanigel, Robert. On An Irish Island. New York: Knopf, 2012.

Kiberd, Declan. "Muiris Ó Súilleabháin, Twenty Years A-Growing". Blasket Island Reflections. Dublin: RTÉ Radio, 2003. Disc 2.5.

—. Irish Classics. Cambridge: Harvard U.P., 2000.

Luce, J.V. "Homeric Qualities in the Life and Literature of the Great Blasket Island". Greece and Rome 18, 2 (1969): 151-168.

Mac Conghail, Muiris. The Blaskets: A Kerry Island Library. Dublin: Country House, 1987.

Ó Fiannachta, Pádraig. "Muiris Ó Súilleabháin, Twenty Years A-Growing". Blasket Island Reflections. Dublin: RTÉ Radio, 2003. Disc 2.16.

Ó Laoire, Lillis. "Augmenting Memory, Dispelling Amnesia: The Songs of Róise Uí Ghrianna". Dublin Review of Books 17 (2011). 8 October 2017. http://www.drb.ie

O’ Luing, Seán. “George Thomson”. Classics Ireland 3 (1996): 141-62. 12 March 2015. http://www.jstor.org/stable/25528296.

O’Sullivan, Maurice. Twenty Years A-Growing. Nashville: J.S. Sanders \& Company, 1998 (1933).

Póirtéir, Cathal, prod. Blasket Island Reflections. RTÉ Radio. Issued as a CD set with illustrated booklet for RTÉ. Dublin: RTÉ Radio, 2003.

Quigley, Mark. "Modernity's Edge: Speaking Silence on the Blasket Islands". Interventions 5, 3 (2003): 382-406. 8 October 2017. DOI: 10.1080/1369801032000135639.

Thomson, George. "Muiris Ó Súilleabháin, Twenty Years A-Growing". Blasket Island Reflections. Dublin: RTÉ Radio, 2003. Disc 2.3.

. 1998. Island Home: The Blasket Heritage. Dingle: Brandon, 1998.

Titley, Alan. "Muiris Ó Súilleabháin, Twenty Years A-Growing". Blasket Island Reflections. Dublin: RTÉ Radio, 2003. Disc 2.4.

Received: 19 May 2017 Revised version accepted: 21 October 2017

Thomas F. Shea is Associate Professor of English at the University of Connecticut. His current research focuses on Ireland's Blasket Island writers, primarily Tomás O'Crohan, Peig 
Sayers, and Maurice O'Sullivan. He is the author of Flann O'Brien's Exorbitant Novels (1992), which received an "Outstanding Academic Book Award" from the Association of College and Research Libraries. His articles on Flann O’Brien, Patrick McGinley, Tomás O'Crohan, and Peig Sayers have appeared in a variety of journals such as Eire-Ireland, New Hibernia Review, Irish Studies Review, Twentieth Century Literature, The Brazilian Journal of Irish Studies, and The Canadian Journal of Irish Studies.

blasket69@aol.com 